\title{
SOVIETIZATION OF THE BALTIC STATES Independence Negotiated, Then Stolen
}

WILLIAM SADD

THIS ARTICLE EXAMINES THE FORCES AND CIRCUMSTANCES OF THE EARLY 1940 S DURING WHICH A UNIQUE CLIMATE WAS CREATED FOR THE SOVIETIZATION OF ESTONIA, LATVIA, AND LITHUANIA. IT ALSO CONSIDERS THE LEGAL ASPECTS OF THE CASE, NAMELY THE INTEGRATION OF THESE THREE INDEPENDENT, SOVEREIGN STATES INTO THE SOVIET UNION WHICH VIOLATED NEARLY ALL MEASURES OF INTERNATIONAL LAW. THIS, HOWEVER, WAS MET WITH LITTLE RESISTANCE FROM THE INTERNATIONAL COMMUNITY, PRIMARILY BECAUSE OF THE RISE OF NAZI GERMANY, THE GENERAL CHAOS IN THE EARLY YEARS OF WORLD WAR II, AND THE SHIFTING ALLIANCES ALONG THE EASTERN FRONT. WITH MANY FORMER SOVIET REPUBLICS IN THE SPOTLIGHT TODAY STRUGGLING TO STABILIZE AS INDEPENDENT STATES, AND WITH THE RUSSIAN FEDERATION STILL OCCUPYING SEVERAL TERRITORIES OF THE FORMER SOVIET UNION UNDER THE AUSPICES OF PEACEKEEPING MISSIONS, THE RELATIVELY SETTLED CASE OF THE BALTIC STATES SERVES AS EXAMPLE TO ANALYZE PROCESSES OF SOVIETIZATION, AND SHOULD AID IN FOSTERING GREATER INTEREST IN THE VARIOUS WAYS BY WHICH DESOVIETIZATION IS OCCURRING IN THE CONTEMPORARY WORLD. 


\section{INTRODUCTION}

By I940, the Baltic States were firmly and decidedly trapped in the doom of their own geo-strategic location. Caught between the dangerous and concurrent rises of Nazi Germany and the Soviet Union, the Baltic States had few feasible options outside of cautious, prudent diplomacy. The three Baltic countries, Lithuania, Latvia, and Estonia, while largely unrelated historically, shared the common plight of having been marginalized under the Russian Empire, and subsequently finding internationally recognized independence following its collapse. This independence, however important to the Baltic mentality and diplomacy abroad, would last for not even a quarter of a century.

The trans-Baltic realization of independence, though principally a result of the Russian Revolution and the ensuing dissolution of the Russian Empire, must also be viewed within the context of the horrors and irrefutable devastation that devoured Eurasia following the First World War. As a result of the war and its ruin, much of Europe and parts of Asia witnessed a total reorganization of their political geographies, as well as the restructuring of an international balance. The redrawing of maps was also related to the break-up of the three great land-based empires which had dominated a large portion of greater Eurasia: the Russian Empire, the Austro-Hungarian Empire, and the Ottoman Empire.

In examining Baltic national emergence and its corresponding defeat, it is important to recognize both the broader parallels and specific connections among the Baltic States, as well as the unique differences between the three. With the most obvious observation being modern paternity, it is worth noting that the emergence and re-emergence of several of the Central and Eastern European independent nation-states-especially Finland, Poland, and the three Baltic states: Latvia, Estonia, and Lithuania ${ }^{\mathrm{ii}}$ — was a direct result of the disintegration of the Eurasian empires, notably the Russian and Austro-Hungarian Empires. The individual experiences and grand narratives of the three, however, were markedly different in several respects.

Latvia's emergence as an independent country in I9I8 was a defining national and, in some ways, ethno-national moment for the Latvian peoples. ${ }^{\text {iii }}$ At the conception of the Latvian state, the Latvians were already well-acknowledged and documented as being an ancient people with a unique, Baltic, Indo-European language. But while the Lithuanians had, at one point in history, established an empire in Eastern Europe in conjunction with Poland, the Latvians had never before been united as an independent political entity. ${ }^{\text {iv }}$ And thus, the year I9I8 saw the inception of the First Latvian Republic. ${ }^{v}$ Concurrently, Estonia had come from different historical, linguistic, and cultural ties which were largely connected with Finland and thus had different experiences from the other Baltic countries. ${ }^{v i}$ Estonia emerged following the upheavals of the First World War, the collapse of tsarist Russia, and the defeat of Imperial Germany, as a modern, unicamerally legislated, liberal Estonian nation. ${ }^{\text {vii }}$

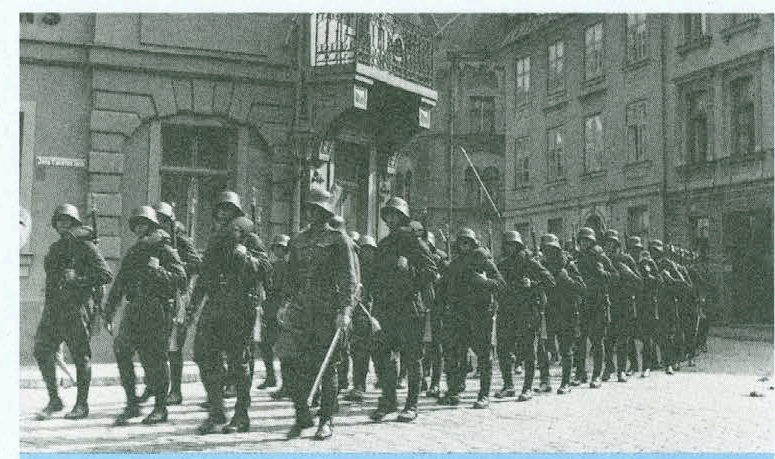

FOLLOWING WORLD WAR I, LATVIA WAS AN INDEPENDENT STATE WITH ITS OWN STANDING ARMY.

Despite the differences from country to country and from ethnicity to ethnicity, the Baltic experience as a total, indissolvable focus is certainly contendable to a great extent. To be sure, the Baltic States were experiencing a Western type of institutional modernization and renovation. ${ }^{\text {viii }}$ There is surely a unified, common Baltic identity which, to a large 
extent, emerges as a Baltic factor in times of confusion-as it did during this period of 'independence'. ix Moreover, from this perspective, it is important to appreciate that the three Baltic States were increasingly inundated with bipolar manipulations from their two evermore powerful neighbors, the Soviet Union and Nazi Germany, which truly bound and connected such a 'Baltic factor'. The mark of the demise of the Baltic States lay entirely in these inter-war years, which were concomitantly their inter-empire years of independence.

During the innumerable contrived and natural shifts of this inter-war period the major surviving powers of the First World War succeeded and progressed as per their own political and military calculations. The United States, for example, was riding a wave of mostly inter-war inaction, while Great Britain, France, and the rest of Western Europe were largely utilizing any and every possible avenue of preclusion, coming in the form of subservience and acquiescence toward the increasingly international dictatorship of Hitler, all in an attempt to avoid a follow-up to World War I. ${ }^{x}$ Ironically, the failures of Western Europe's attempts to appease Hitler ran straight into Nazi Germany's consumptive actions in the late I930s, thereby leading to the Second World War.

Toward the end of the I930s, the Baltic States could not support any hopes of preserving their independence through balancing the dichotomy of the aforementioned growing Nazi and Soviet hegemonies. In conjunction with their according policies with said neighbors, this balance was what unified the Baltic States to a great extent in those precarious pre-I940 years. But it was the irrevocable and ineradicable memory, however, of Estonian, Latvian, and Lithuanian consumption, in toto, into the Union of Soviet Social Republics (USSR) by way of "voluntary incorporation," $\mathrm{xi}$ as well as the forcible, unmitigated, and systematic Sovietization of the predominantly unwilling Baltic peoples, that unified the three countries in those perilous postannexation years. By the summer of I940, the independent Baltic States of Estonia, Latvia, and
Lithuania-independent states and symbols for perhaps the last strand of inter-war attempts at general international bipartisanship and neutrality in Central and Eastern Europe-were irrefutably victimized and robbed of their independence by way of imperial design.

\section{THE MOLOTOV-RIBBENTROP PACT}

In order to best comprehend the complexities of the Soviet infiltration of the Baltic States from I940-4I, the span of a single year, it is first worth examining how Soviet foreign policy and its main players prefaced the summer of I940. There was a vast degree of political calculation and international presupposition on the part of Moscow in order to facilitate such an easy annexation of three independent countries. Concurrently, in the post-World War I years there were immeasurable apprehensions, anxieties, fears, and ultimate inadequacies and shortcomings regarding transEuropean and trans-national affairs. ${ }^{\text {xii }}$ Even still, deconstructing the road to what became the hegemonic rumination, systematic annexation, and eventual Sovietization of the Baltic States, leads to a foundation of events being rooted most closely in the late I930s agreements between the Soviet Union and Nazi Germany.

Soviet-German rivalries began to really flourish with Germany's rise in the early I930s. xiii As Germany continued to strengthen itself and precipitously weaken its neighbors throughout the I930s, the Baltic States focused much of their attention and interest on pursuing neutrality as much as possible, while at the same time attempting to achieve a very difficult balance between German and Soviet regional interests. ${ }^{\text {xiv }}$ All of these attempts, however, were ultimately doomed by the negotiations between the Soviet Union and Germany, culminating in the August 23, 1939 signing of the Molotov-Ribbentrop Agreement. ${ }^{\mathrm{xv}}$

The agreement, also referred to as the Molotov-Ribbentrop Pact or the Nazi-Soviet Pact of Non-Aggression, in some preliminary ways, solidified what was already a long-standing Baltic fear of the imperial aims of its neighbors. To a certain extent, the pact superficially and temporarily disen- 
tangled some of the increasing tensions and complexities surrounding the Nazi-Soviet balance of power. While not expressly mentioned in the text of the pact, Eastern Europe and its constituent space between the Soviets and Nazis was divided into spheres of influence. ${ }^{x v i}$ This was stipulated in a secret supplementary protocol to the pact, as now recognized by historians. ${ }^{\text {vii }}$

Molotov and Ribbentrop's I939 pact was, in many ways, the result of several examinations made by each side on the balance of Eastern Europe and the Baltic States (including Finland), with regard to the strengthening of the pact's signatories and Europe's undeniable descent into war. The pact was a ten-year agreement of non-aggression and was conceived after a series of discussions between Ribbentrop and Stalin. ${ }^{\text {xviii }}$ The importance of this emerged through the affordance and emergence of the aforementioned secret protocol.

In the discussions surrounding the preparation of the protocol, it became clear that both sides knew each other's desires well enough. While establishing Germany's claim to Poland, Hitler recognized Stalin's long-willed desire for the Curzon Line as the Russian border; and he gave it to him. ${ }^{\text {xix }}$ As per the secret protocol in the August agreements, the Soviet Union was to have Estonia, Latvia, Bessarabia, and the eastern part of Poland as its sphere of interest and according influence. ${ }^{\mathrm{xx}}$ And though Lithuania was initially to be Germany's concern, ${ }^{x x i}$ it was subsequently added to the Soviet sphere in September of that year. ${ }^{\text {xxii xxiii }}$ At the same time, however, both sides recognized the validity of the Lithuanian claim over Poland regarding the Vilnius region. ${ }^{\text {xiv }}$
Unsurprisingly, shortly after the pact, Hitler proceeded to invade Poland on September I, I939, and saw not a glance from the Soviet side, as promised; Stalin subsequently moved in from the east on September I7. And while the details of the protocol and the ensuing systematic eightmonth deconstruction of Estonia, Latvia, and Lithuania would see each of the Baltic States dismembered as independent states and simultaneously incorporated into the USSR as union republics, it is worth noting that almost every article of the protocol contradicted principles of international law, and few states resolved upon recognizing Stalin's patent annexation.

\section{MUTUAL ASSISTANCE AGREEMENTS AND "VOLUNTARY INCORPORATION"}

Throughout the I920s and into the early I930s, the Baltic States had all pointedly concluded agreements of non-aggression and neutrality with the Soviet Union. xxy The three also signed an extended Treaty of Peace and Cooperation in I934, ${ }^{\text {Xxvi }}$ as well as a similar pact of neutrality and non-aggression with Nazi Germany in I939. ${ }^{\text {xxvii }}$ The complication was of course the lack of continuity in the realities of the people. While the three states were all ultimately conquered because of their undeniable geo-strategic importance between the Soviet Union and Nazi Germany, each had different levels of concern in response to each power. The Soviet Union was more of a direct threat for Estonia. Nazi Germany and the perpetual question over Vilnius with Poland were major concerns for the Lithuanians; Latvia was troubled mostly by Soviet Russia. Although such a 'Baltic Entente' and other unifying exchanges were attempted, xxviii the three countries were often divided when it came to foreign defense and policy in the years leading up to annexation. xxix Further still, by the time of the Molotov-

\section{"The progression of the treaties ... truly showed the extent to which the Baltic States were manipulated, exploited, and then systematically seized ..."}


Ribbentrop Pact and during that final year before annexation, belated Baltic attempts at convening and coordinating efforts for preservation provided little more than a pretext for Stalin's I940 absorption and occupation of the three states. $\mathrm{xxx}$

The progression of the treaties, however, especially at the close of the I930s, and especially with regard to the Soviet Union, truly showed the extent to which the Baltic States were manipulated, exploited, and then systematically seized; the calculated nature of all this is indelible. Undoubtedly, the Baltic States would have been occupied once World War II commenced. But the manipulative procedure by which Moscow achieved mutual assistance pacts and military and economic agreements with Latvia, Lithuania, and Estonia cannot be ignored.xxxi

Serious questions and arguments come to mind regarding the legality surrounding the Soviet incorporation of the Baltic States. The methodology behind their incorporation was purposeful. Molotov himself said to a Lithuanian minister in July, I940 that the goal was to absorb and assimilate the states into the USSR, citing that Russia had desired the Baltic region since Ivan the Terrible, and that small, independent states had no future. ${ }^{x x x i}$ And while the three states had probably still hoped for a potential rift in German-Soviet relations, xxxiii Latvian, Lithuanian, and Estonian leaders surrendered their countries' autonomies by signing their respective mutual assistance pacts with Moscow.xxxiv Moreover, while Estonia, for instance, allowed Soviet air strikes off of Estonian bases during the I939-40 Winter War with Finland (largely to avoid antagonizing Moscow), ${ }^{\mathrm{xxxy}}$ the legal claims regarding the progressive Soviet encroachment remain.xxxvi In fact, the Kremlin's subjugation and r940 absorption of the Baltic States contravened a series of treaties existing between Moscow and the three republics including: the I920 peace treaties which had outlined the maintenance of peace and good-neighbor principles; the I929 "protocol" repudiating war, as sponsored by Maxim Litvinov; the I926-32 treaties for peaceful conciliation and non-aggression; the 1933 con- ference on aggression which indicated and itemized that no political, economic, military, or other claims may serve as validation for an armed offense or invasion; and finally, the 1939 mutual assistance treaties which plainly and unmistakably promised "never to infringe upon the sovereign rights of these states, with particular pertinence to their political structure and social and economic organization."xxxvii

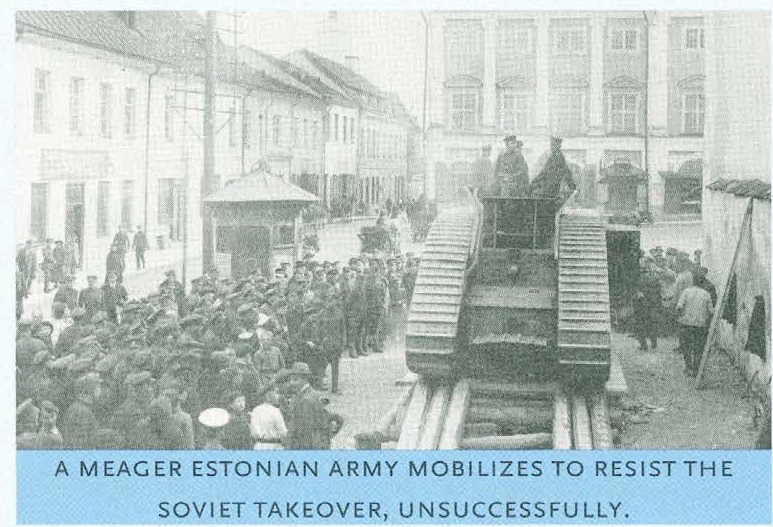

Soviet incorporation of the Baltic States was illegal; it undeniably infringed upon each of the countries' internationally recognized legal right to be treated as a sovereign nationseemingly unconditional rights, despite the previously discussed Molotov-Ribbentrop Pact, approval or disapproval from Moscow, or any local referendum.xxxviii Because of these unconditional rights, as well as other forces such as international pressures from allies and geo-strategic apprehensions, few states recognized Soviet annexation of Estonia, Latvia, and Lithuania in I940. Moreover, the annexation must be viewed as a sort of argument; it was-to be sure-a prosecution. Moscow went to great lengths contriving pretexts for more debilitating actions with its Baltic neighbors; but at the same time, it made equally critical strides to disguise the integration of the states as a popular upheaval, national transformation, and corresponding alliance. 
THE SOVIET BALTIC STATES: EARLY

\section{POLITICAL SHIFTS AND INTER-BALTIC}

\section{COMPLEXITIES}

By June, I940, Stalin was ready to cash in on the Baltic Republics.xxxix With each republic, beginning with Lithuania, Moscow alleged a series of accusations citing that Lithuanian, Latvian, and Estonian governments needed to be replaced with governments capable of upholding the previous agreements regarding mutual protection and assistance. With each country given the same ultimatum, Lithuania on June I4, I940, ${ }^{\mathrm{xl}}$ and Latvia and Estonia on the I6th of that same month, xli xlii the option was either to relinquish the government or face invasion. With the Red Army already at the borders with great numbers of troops (Estonia had approximately 25,000 Red Army soldiers at its border), xliii the government of each respective Baltic state viewed concessions and surrender as the only possible option. The Soviet Union had not offered an ultimatum; it handed each Baltic State a diktat.

With each state having capitulated with little or no hesitation, the Red Army immediately poured in. xliv Shortly thereafter, elections were held, in a manner mocking the democratic process, all attempting to legitimize the new governments; the communist parties in each state won overwhelmingly, taking as much as 95 percent of the Lithuanian vote. xly From here, the process of Sovietization and systematic deconstruction, or reconstruction per Soviet vision, and inclusion within the USSR occurred fairly rapidly.

In rather traditional Soviet fashion, Moscow imposed its pattern of forced incorporation and Sovietization in each Baltic State quite formulaically. There was a structure to the incorporation and Sovietization based upon a central hypothesis: compliance of its fragile and 'ineffectual' national political adversaries would preclude, to an extent, by which an avenue could be taken advantage of, and essential submission of the subjected states would occur. The systematization of the Baltic States naturally followed after initial Soviet successes, while further progressing in tandem: the Communist parties were legalized in each country, while former ruling parties were banned, effectively creating one-party systems; non-Communists were banned by July, I940 from Baltic governments, and the majority of cabinets were Communist. That same month, two waves of mass arrests removed uncooperative elites from the Baltic political scene. Then, elections were held and the poll results were doctored to Soviet desires when needed. The newly elected People's Diets convened in July and formally requested admittance into the USSR as SSRs; and finally, by August, I940, Moscow approved the Diets' requests, creating Estonian, Latvian, and Lithuanian republics within the Soviet Union. xlvi

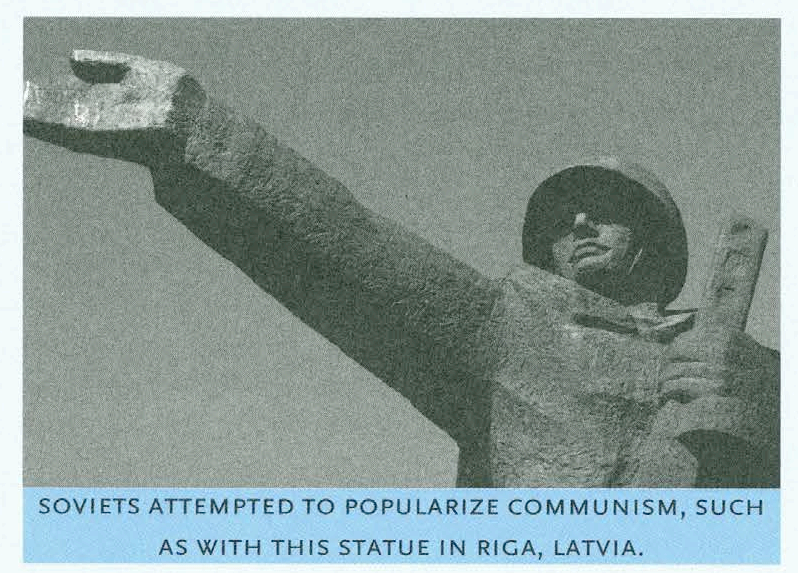

While Moscow went to great lengths to make it seem as though the I940 Baltic transition and its succeeding political reconfiguration was popularly driven, the Latvian, Lithuanian, and Estonian communist parties had, in fact, been very small and largely unfavorable to the general Baltic populations. Upon Soviet occupation and legalization of the Communist Party in the three countries, membership was negligible. In Lithuania, party membership stood between I,500 and I,600 at best; xlvii it was only between 800 and I,000 in Latvia; and still fewer, only I33 to I50 in Estonia.xlviii xlix Of course, some legitimate, new Communist support in the Baltic States was coming from crypto-Communists who had previously posed as affiliates 


\section{"While rural economic life was subjected to less sweeping changes in the first year of Soviet transformation, the urban sector witnessed massive changes in banking, commerce, industry, and transportation."}

of other parties. By and large however, the native Communist parties of the three Baltic states had been inconsequential, sectarian, and clandestine.

The above figures suggest that any perceived support for the new, ruling, Communist parties in the Baltic States must be taken critically. Surely, there were a number of new Communist Party members or pro-Communist sympathizers. Even still, this cannot be examined outside the framework of Soviet pressures which created a simple reality: those organizations which did not align themselves with the new forces soon faced the reality of their own forced disintegration. ${ }^{1 i}$

Concurrently, there was a fair degree of contrived support for the Communist Party via foreign implantations. The USSR had appointed high-ranking envoys for each Baltic State in order to oversee operations and Soviet development. Most notably, Leningrad Party leader Andrei Zhdanov was sent as the emissary to Estonia, while Vladimir Dekanozov and Andrei Vyshinskii were sent to Lithuania and Latvia, respectfully. ${ }_{\text {lii }}$ Aside from the above, a fair number of Soviet citizens were brought in as Communists of Baltic extraction, if you will, for the purpose of dictating political life and its direction. liii At the same time, indigenous party members were not wholly inexistent. While still miniscule compared with the population of Lithuania, the Communist Party had achieved some support. With the invasion of the Red Army, and perhaps using this as a justification for membership, a number of new members from various social strata joined the party in Lithuania. Among the higher fraction of members was a
Jewish minority, representing approximately 36 percent of the party. liv This high percentage of Jews can be attributed to a number of reasons, but perhaps the most comprehensible reason is simply that a substantial number of Jews pragmatically benefited from the new order, as they were afforded greater access to higher education and better jobs than were previously available to them. ${ }^{\text {lv }}$ Surely though, the prevailing sentiments among most Jewish communists were deeply rooted in fear for physical survival. Ivi While the Jews would not be spared from the mass deportations that were to come, they would be largely identified by Lithuanians and Latvians as part of the Communist regime, and would consequently face backlash from these local populations according to an easily propagated 'scapegoat' mentality when the Nazis invaded in the summer of I94I.

\section{SOVIETIZED BALTIC ECONOMICS}

For all of the deception and convolution that came with notorious political shifts in the impressive first year under the Soviet Union rule in the Baltics, the Soviet regime had dedicated the majority of its energies into the transformation of Baltic urban economies. Ivii While rural economic life was subjected to less sweeping changes in the first year of Soviet transformation, the urban sector witnessed massive changes in banking, commerce, industry, and transportation. lviii Further still, the changes occurred almost overnight, with the banks and large-scale industries being almost immediately nationalized, and smaller private businesses, with increased rents and taxation, finding continued existence nearly impossible. . $^{\text {ix }}$ 
Flawed wage, monetary policy, and inflation led to a nosedive in living standards. ${ }^{\mathrm{lx}}$ Nearly all industry and transportation was rapidly falling under the aegis of the state and its operatives. The Soviet ruble was introduced as the new form of currency, and at drastically low exchange rates; anyone possessing savings of more than I, O०o rubles had the excess confiscated by the government. lxi Moreover, with collective farms on the mind of many Soviet authorities, nearly Ioo collective farms were established in Estonia alone during I940-4I. ${ }^{\text {xii }}$ During the collectivization period, many new farmers were favored, while the recognized, medium-sized farmers who had established themselves during the years of independence were, in many ways, now discriminated. ${ }^{\text {lxiii }}$

From June, I940 to June, I94I, many other new guidelines including increased length of the work day and intense new restrictions on movement between jobs, coupled with policies which enforced the confiscation of private land, ${ }^{\text {, xiv }}$ and the still-increasing political ten-

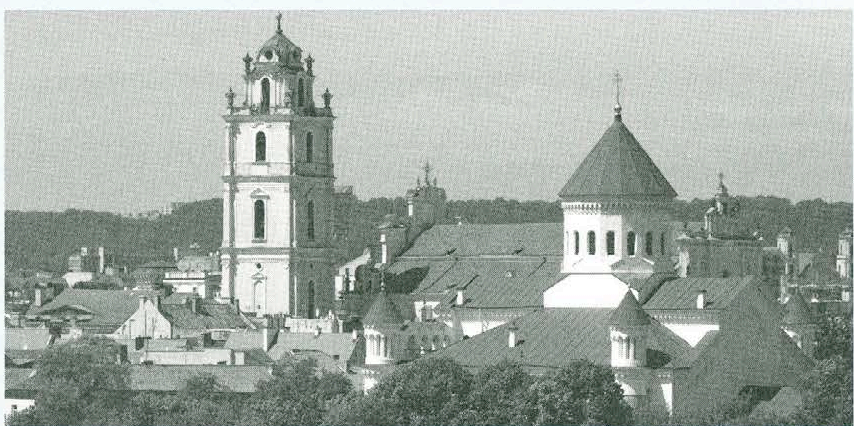

MANY CITIZENS OF VILNIUS, LITHUANIA WERE DEPORTED TO SIBERIA AND SOVIET ASIA. ples massively organized in enclaves of prepared resistance on the other.lxvi The Nazi-German troops had entered countries which had just been bestowed by Stalin and his supporters with what would eventually become known as the Year of Terror. ${ }^{\text {xvii }}$

Over the course of I940-4I, in addition to all the aforementioned changes affecting Baltic society, Estonia, Latvia, and Lithuania saw mass levels of emmigration and forced deportations. Primarily in the form of repatriations of the socalled Baltic Germans back to Germany (which took place in two waves in I940-4I), many others military officers, anti-Communists, and political rivals to the Soviet administrations fled the region. lxviii This exodus of people was followed by an even more haunting and unforgivable purging of local peoples, as presided over by the Soviet Union. Of course, it was planned in advance as a repressive measure to fracture any possible resistance to Soviet rule in the area; ;xix that was the target. This vision became sions, pointedly undercut what were relatively stable social infrastructures, especially in Latvia, and ultimately heightened class antagonisms. ${ }^{1 \times v}$ And while the drastic regulations in the economic realm were harsh toward the already fairly established socio-economies of each country, they seem minor compared with the brutality that would face those deposed Baltic peoples in the final moments of Soviet rule prior to the June, I94I Nazi-German invasion.

\section{THE PURGES AND THEIR INERADICABLE}

\section{IN HERITANCE}

When the German troops invaded the Baltic States on June 22, I94I, they found peoples in chaos, emotionally troubled and demographically unstable on the one hand, and peo- realized by Soviet bureaucrats as they deported mass numbers of intellectuals, former government officials, members of the bourgeoisie, and other 'unreliable elements' to Siberia and Soviet Asia. ${ }^{\mathrm{xx}}$ This of course-while undoubtedly a major aspect of the purges - was only the theoretical portion; in reality, Soviet repression hit a tremendous amount of innocent and entirely neutral people within the three countries. ${ }^{1 \times x i}$

Ironically, however, because of the general repression and terror of the deportation experiences, and the fact that the victims were often suggested at random, as available evidence suggests, lxxii the aim of the brutal Soviet repressions failed at-large to achieve their goal. Further still, the purges 
were probably counterproductive. In the one year before the Soviet retreat from the Baltic territories, it is estimated that, through deportations and executions, the three countries combined lost over I0०,000 members of their populations with an approximate break down of 39,000 in Lithuania, 35,000 in Latvia, and nearly 61,000 in Estonia. ${ }^{1 x i i}$ Numbers from Estonia were the highest since the Estonians were under Red Army occupation for the longest period of time prior to German invasion; nearly 2,000 Estonian citizens had been executed over the course of the years, while an additional 33,000 were forcibly conscripted into the Soviet Army. Total population losses for Estonia alone neared six percent. ${ }^{\text {lxxiv }}$ Further still, in the last week of Soviet occupation, tens of thousands of Baltic people were deported to Russian work camps. This came to fruition in the disastrous night in Baltic memory that was June I4, I94I, when some I2,000 Estonians, I5,000 Latvians, and 34,000 Lithuanians were deported. lxxv

The trans-Baltic reality for 1940-4I was as illustrated above: a year of radical change, death, exodus, mass deportation and conscription, and in many ways general terror. Could this have been justified by Soviet administrators and functionaries as having been a necessary cruelty for the greater good of defeating the Nazis and re-stabilizing Europe? Perhaps. If meant as a policy of repression, it was surely flawed, as massive armed insurrections throughout the Baltic States in I94I showed irrefutable rejection of the ruling Soviet regime. Ixxvi But even still, such a line of reasoning does not explain the overtly brutal treatment toward the Estonians, Latvians, Lithuanians, and the respective minority groups of their societies; nor does it provide an adequate justification for the deportation of the hundreds of thousands sent to Siberia and Soviet Asia; ${ }^{\mid x x v i i}$ nor any reasonable account that would vindicate Molotov and Moscow's unquestionably calculating manipulations that led to the private recognition of Eastern European spheres of influence, and subsequently saw the systematic deconstruction and Sovietization of the three Baltic States. For I940-I94I, the memory is glaring and seemingly ineffaceable. However as inheritors of such a history, of a destroyed and ultimately regained independence, and as new members of the European Union, the difficult challenge will be for the peoples of all three Baltic States to move forward through these post-Soviet years and the discord of ever-shifting balances of power, to afford a new way with their still ever-influential neighbor to the east.

\section{ENDNOTES}

i. Smith, Jeremy (495)

ii. Read (22)

iii. Pabriks \& Purs (I4)

iv. Ezergailis (35)

v. Ibid. (37)

vi. Much of what was evident with Estonia's development as an independent nation between I9I7 and I920, at the turn of that decade, and throughout the I920s, was rooted in a series of agrarian and educational reforms which had been implemented in Estonia in the first half of the igth century. And consequently, following these advances came a determined enough Estonian national awakening in the 186 os. Some argue that many of the advancements of Estonia following independence-insofar as the fair degree of political, cultural, and socioeconomic modernization that was evident-emerged as a result of several 'Estonian' developments that had begun during Igth century. Toivo U. Raun speaks more of this in his book "Estonia and the Estonians."

vii. Raun (99)

viii. Norgaard \& Johannsen (55)

ix. Ibid.

$\mathrm{x}$. Many argue today that failures of Anglo-French appeasement hit its nadir with the virtual rape of Czechoslovakia. While Austria had been annexed to Nazi Germany with little more than a glance from other European nations, Czechoslovakia's destruction was internationally presided over and allowed to occur without even the presence of a single representative from Prague. Conclusively so, it would not be so unfair to recognize that this in many ways - as perhaps the most significant

Central European preface to the Second World War-saw the pointed ruin of hope for any real continuity of Central European democracy from those uncertain inter-war years.

xi. Lacis (II)

xii. This can also be read-with regards to the United States, among other major non-European players on the international stage - as trans-continental.

xiii. Norgaard \& Johannsen (45) 
xiv. Ibid.

xv. Sakwa (235)

xvi. Westwood (II3)

xvii. Sakwa (238)

xviii. Westwood (II3)

xix. Roskin (45)

xx. Yekelchyk (537)

xxi. Westwood (II3)

xxii. Yekelchyk (537)

xxiii. It is also worth recognizing here that while the Baltic

States, Poland, Bessarabia, etcetera were undoubtedly di-

vided amongst the Soviets and Nazis, the Molotov-

Ribbentrop game and secret handlings in no way

acknowledge that spheres of interest or influence meant

automatic right to the integration, incorporation, or

absorption of the subject territory. This, however,

happened over the course of the war in effectively every

case.

xxiv. Sakwa (238)

xxv. Yekelchyk (533)

xxvi. Haab (126)

xxvii. Yekelchyk (533)

xxviii. Aragon (346)

xxix. Kirby (80)

xxx. Ibid.

xxxi. Westwood (II4)

xxxii. Smith, David J. (28)

xxxiii. Kirby (78)

xxxiv. Ibid. at 8 I

xxxv. Smith, David J. (26)

xxxvi. The fact that Soviet forces launched attacks on

Finland from Estonia bases at all — whether tacitly permitted or not-was concomitantly a violation of the aforementioned mutual assistance pact which had been signed by both Soviet and Estonian representatives.

xxxvii. Clemens (54)

xxxviii. Ibid. at 55

xxxix. Sakwa (248)

xl. Clemens (52)

xli. Smith, David J. (27)

xlii. Pabriks \& Purs (24)

xliii. Smith, David J. (27)

xliv. Clemens (52)

xlv. Snyder (85)

xlvi. Clemens (53)

xlvii. Eidintaas (I33)

xlviii. Kirby (79)

xlix. Clemens (54)

1. Ibid.

li. Kirby (79) lii. Clemens (53)

liii. Ibid.

liv. Eidintaas (I33)

lv. Kirby (79)

lvi. Eidintaas (I35)

lvii. Smith, David J. (33)

lviii. Raun (I5I)

lix. Smith, David J. (33)

lx. Ibid.

lxi. Raun (I5I)

lxii. Smith, David J. (34)

lxiii Raun (I52)

lxiv. Smith, David J. (34)

lxv. Ezergailis (39)

lxvi. Ibid. at 40

lxvii. Lacis (I5)

lxviii. Ezergailis (38)

lxix. Shtromas (86)

lxx. Yekelchyk (538)

lxxi. Shtromas (87)

lxxii Smith, David J. (34)

lxxiii Shtromas (87)

lxxiv. Smith, David J. (34)

lxxv. Clemens (5)

lxxvi. Shtromas (90)

lxxvii. Roskin (I8)

\section{REFERENCES}

Aragon, Louis. 1964. A History of the USSR: from Lenin to Krushchev. London: Weidenfeld and Nicolson.

Clemens, Walter C. I991. Baltic Independence and Russian Empire. London: MacMillan.

Eidintaas, Alfonsas. 2003. Jews, Lithuanians, and the Holocaust. Vilnius, Lithuania: Versus Aureus.

Ezergailis, Andrew. 1996. The Holocaust in Latvia, 19411944: The Missing Center. Riga, Latvia: The Historical Institute of Latvia.

Haab, Mare. I998. “Estonia.” Bordering Russia: Theory and Prospects for Europe's Baltic Rim. Ed. Mouritzen, Hans. Aldershot, UK. pp. Io9-I3O. 
Kirby, David. 1994. "Incorporation: The MolotovRibbentrop Pact.” The Baltic States. Ed. Smith, Graham. London. pp. 69-85.

Lacis, Visvaldis. 2006. The Latvian Legion: According to Independent Observers. Riga, Latvia: Jumava.

Norgaard, Ole \& Johannsen, Lars. 1999. The Baltic States after Independence. 2nd ed. Cheltenham, UK: Edward Elgar.

Westwood, J. N. 1966. Russia, 1917-1964. London: B.T. Batsford.

Pabriks, Artis \& Purs, Aldis. 200I. Latvia: The Challenges of Change. New York: Routledge.

Raun, Toivo U. 200I. Estonia and the Estonians. 2nd ed. Stanford: Hoover Institution Press.

Read, Christopher. 200I. The Making and Breaking of the Soviet System: An Interpretation. Hampshire: Palgrave.

Riasanovsky, Nicholas V. 1984. A History of Russian. 4th ed. Oxford: Oxford University Press.

Roskin, Michael G. I991. The Rebirth of East Europe. Upper Saddle River, NJ: Prentice Hall.

Sakwa, Richard. I999. The Rise and Fall of the Soviet Union, 1917-1991. London: Routledge.

Shtromas, Aleksandras. 1994. "The Baltic States as Soviet Republics: Tensions and Contradictions.” The Baltic States. Ed. Graham Smith. London. pp. 86-I20.

Smith, David J. 200I. Estonia: Independence and European Integration. London: Routledge.
Smith, Jeremy. 2006. "Non-Russians in the Soviet Union and After." The Cambridge History of Russian, Volume III: The Twentieth Century. Ed. Ronald Grigor Suny. Cambridge. pp. 495-52I.

Snyder, Timothy. 2003. The Reconstruction of Nations: Poland, Ukraine, Lithuania, Belarus, 1569-1999. New Haven: Yale University Press.

Yekelchyk, Serhy. 2006. "The Western Republics: Ukraine, Belarus, Moldova and the Baltics." The Cambridge History of Russian, Volume III: The Twentieth Century. Ed. Ronald Grigor Suny. Cambridge. pp. 522-558. 